\title{
Influence of Two Intercropping Patterns of Onion with Sugar Beet on Some Foliar Diseases and Productivity of Both Crops.
}

\section{Khalifa, M.M.A. ${ }^{1}$; El-Mansoub, M.M.A. ${ }^{2}$; Ibrahim,} M.M.A. ${ }^{1}$ and Ata, A.A. ${ }^{1}$

1- Plant Pathology Research Institute, Agricultural Research Center, Giza, Egypt.

2- Sugar Crops Research Institute, Agricultural Research Center, Giza, Egypt.

Two intercropping patterns of onion $(\mathrm{ON})$ with sugar beet $(\mathrm{SB})$ namely (ON ridge: ridge $\mathrm{SB}$ ) and (side: side "ON+SB ridge: ridge SB alone") were carried out to investigate their effect on severity of four foliar diseases. The target diseases were downy mildew and purple blotch of onion, as well as Cercospora leaf spot and rust of sugar beet under natural infection under field conditions at Damietta Governorate in 2016/17 and 2017/18. Also, the advantage of the two intercropping patterns on yield production of both tested crops, as well as land equivalent ratio (LER) was evaluated. The two intercropping patterns significantly decreased disease severity of both downy mildew and purple blotch of onion, as well as, Cercospora leaf spot and rust diseases of sugar beet compared to monoculture cultivation of each crop in the two seasons. Intercropping patterns of onion: sugar beet, i.e. (1 ridge $\mathrm{ON}: 3$ ridges $\mathrm{SB}$ ) and (1ON: $1 \mathrm{SB}$ alternately) were the most superior in decreasing disease severity of both onion downy mildew and purple blotch diseases. However, intercropping pattern (3 ridges $\mathrm{ON}: 1$ ridge $\mathrm{SB}$ ) and (1ON: $1 \mathrm{SB}$ alternately) were the most effective patterns for decreasing both Cercospora leaf spot and rust diseases of sugar beet in the two growing seasons. On the other hand, intercropping patterns onion $(\mathrm{ON})$ with sugar beet arranged by side to side, i.e. (1 ridge $\mathrm{ON}+\mathrm{SB}: 3$ ridges $\mathrm{SB}$ alone) and (2 ridges $\mathrm{ON}+\mathrm{SB}: 2$ ridges $\mathrm{SB}$ alone) were the best patterns for decreasing both onion foliar diseases, meanwhile, intercropping patterns (4 ridges $\mathrm{ON}+\mathrm{SB}$ : no ridges with $\mathrm{SB}$ alone) and (3 ridges $\mathrm{ON}+\mathrm{SB}: 1$ ridge $\mathrm{SB}$ alone were the most superior ones for reducing severity of both Cercospora leaf spot and rust diseases during the two seasons. The highest severity of the four tested foliar diseases of the two different intercropping patterns was recorded when either onion or sugar beet was cultivated alone in both seasons. On the other side, most treatments of the two intercropping patterns maximized yield production of onion bulb and sugar beet root yield, and increased land equivalent ratio (LER) compared to each crop cultivated alone with few exceptions. Ridge: ridge pattern of (1 ON ridge: $1 \mathrm{SB}$ ridge alternately) was the best one for maximizing either onion bulb or sugar beet root yields. However, the patterns of (side: side) were (3 ridges $\mathrm{ON}+\mathrm{SB}$ : 1 ridge $\mathrm{SB}$ alone) 
and (1 ridge $\mathrm{ON}+\mathrm{SB}: 3$ ridges $\mathrm{SB}$ alone) were the best for increasing onion bulb yield and root yield of sugar beet, respectively, in both seasons. The results concluded that onion and sugar beet intercropping could be beneficial in reducing foliar diseases and increasing yield of both crops with a maximized LER and economic return for the farmer compared to each crop cultivated alone.

Keywords: Onion, Sugar beet, intercropping, foliar diseases, yield, LER.

Due to growing human population in Egypt, the demand for the different food products is far beyond excess of supplies, which created food security gap. One of the main problems associated with the Egyptian Agricultural system is the low size of cultivated land per farmer. In average, $42.9 \%$ of the farmers own or work in field one feddan $\left(4200 \mathrm{~m}^{2}\right)$ or less (Ahmed et al., 2009). On the other hand, agricultural land for the production of different crops is becoming scarce. Thus, there is an increasing need to maximize the land usage to accelerate productivity gains, which may help in decreasing the food security gap (Salama et al., 2016). In terms of land use, intercropping (growing crops in mixed stands) cultivation greatly contributes to crop production by its effective utilization of resources, as compared to the monoculture cropping system (Zhang and $\mathrm{Li}, 2003$ ). Intercropping system, as an element of sustainable agriculture is regarded as more productive crop raising system than growing them separately (Kumar et al., 2014). Common advantages of different forms of intercropping are intensification of crop production and exploiting more efficiently environments with limiting or potentially limiting growth resources (Trenbath, 1993). Other advantages associated with intercropping are better weed management and pest control (Raheja, 1977), assurance against failure of crop (Kumar et al., 2014), reduced fertilizer requirement (Gao et al., 2014) and better soil fertility and soil conservation (Zhang and $\mathrm{Li}, 2003$ ) than sole cropping. The choice of the component crops in the intercropping cultivation is crucial. Under intercropping system, attention should be given to the crops that can grow together with minimal competition and maximum profit (Abou khadra et al., 2013 and Abdel Motagally and Metwally, 2014). Among the important crops in the Egyptian agricultural system are the onion and sugar beet crops.

Onion (Allium cepa L.), rightly called "queen of kitchen", is one of the oldest known and one of the important crops grown in Egypt and many countries of the world. In addition, it has been reported to be rich in phytochemicals especially medicinal flavonols (Javadzadeh et al., 2009). Egyptian onion is exported to many countries of the world and this crop is greatly desired for its good quality and early appearance in the foreign markets. The total cultivated area of onion crop in Egypt is about 196509 fed. in 2017 (Anon., 2017), produced about 2951000 tons with average of 15.02 ton/fed.. The area distributed in Lower Egypt was 73\%, 17\% in middle Egypt and $10 \%$ in Upper Egypt.

Egypt. J. Phytopathol., Vol. 47, No. 1 (2019) 
Sugar beet (Beta vulgaris L.) is one of the two important sugar crops worldwide. Recently sugar beet surpassed sugar cane in sugar productivity and became the first source of sugar production in Egypt compared to sugar cane. Area of sugar beet had increased significantly, by approximately $25.6 \%$, during the last 35 years in Egypt (Salama et al., 2016). Consequently, the contribution of sugar beet to sugar production in Egypt largely increased to reach $35.5 \%$ of the total sugar production in 2012 (Abdel Motagally and Metwally, 2014). The total cultivated area of sugar beet in Egypt is about 608 thousand fed. at the season 2018: 2019, produced about $12,247,170$ ton beet and 1,528,270 ton sugar (Anonymous, 2019). However, production of sugar is not enough, so the agricultural policy has been given much attention to grow sugar beet to narrow the gap between consumption and production. Increasing the sugar yield per unit area of sugar crops is thus, a national demand and could be achieved by adopting suitable cultural practices and applying intercropping

An agronomic advantage had been demonstrated when onion and/or sugar beet were intercropped with other winter crops. Onion was intercropped with sugar beet (Abdel Motagally and Metwally, 2014), faba been (El Refaey et al., 2018 and Ali and Albayati, 2018), or with rape seed, kale, fenugreek, lentil, linseed, black cumin and dill (Getahun et al., 2018). On the other hand, sugar beet was intercropped with onion and garlic (El-Mansoub et al., 2010, Abdel Motagally and Metwally, 2014 and Badawy, and Shalaby, 2015), wheat, barley, lentil or faba bean (Ismail et al., 2005; Gadallah et al., 2006; El-Mansoub et al., 2010; Abou khadra et al., 2013; Usmanikhail et al., 2013 and Salama et al., 2016).

Several factors have been identified for the low productivity of both onion and sugar beet crops in Egypt. The most important factors responsible for the reduced productivity of onion are the foliar diseases like downy mildew, purple blotch and Stemphylium leaf blight. Downy mildew of onion caused by Peronospora destructor [Berk.] Caspary and purple blotch caused by Alternaria porri (Ellis) Cif., are the most prevalent and dangerous foliar diseases worldwide and cause the major problems of onion production in Egypt (Abdel-Megid et al. 2001 and Mahmoud et al. 2013). However, yield losses reached about $12-75 \%$ in case of downy mildew depending upon growth stage of plants affected and severity of disease (Sugha and Singh, 1991), meanwhile, the yield loss of onion due to purple blotch under favorable conditions varies from 5.0 to $96.5 \%$ (Gupta and Pathak, 1988) and $97 \%$ (Lakra, 1999). These losses mainly result from severe infections in bulb onion crops causing early defoliation, reduced bulb sizes, and poor storage quality of bulbs (Surviliene et al., 2008). Downy mildew can cause serious losses within a short period of time during cool and humid weather conditions (Hoffmann et al., 1996). However, high relative humidity up to $100 \%$ and temperature range from 20 to $28^{\circ} \mathrm{C}$ were optimum for infection by purple blotch (Kumar, 2007).

Meanwhile, many pathogenic fungi attack growing sugar beet plants causing serious diseases under field conditions. Foliar diseases i.e. Cercospora leaf spot 
(CLS) caused by Cercospora beticola and rust caused by Uromyces betae are the most important foliar disease of sugar beet (Ata, 2005; El-Fiki et al., 2007; ElMansoub et al., 2010 and El-Mansoub et al., 2017). Since the two fungi can damage the leaves, it adversely impacts the photosynthetic capacity of plants and reduces yield and result in higher impurities in the juice which reduces sucrose extraction, as well as, induce changes in the biochemical constituents like amino acids, phenols and sugar which may affect quality and yield (Ata, et al., 2005; El-Fiki et al., 2007 and Ata, 2014).

The present study was carried out mainly to evaluate the relative advantage of two intercropping patterns of sugar beet with onion crops on severity of downy mildew and purple blotch in onion, as well as Cercospora leaf spot and rust diseases in sugar beet, as well as on productivity of both crops and land equivalent ratio (LER).

\section{Materials and Methods}

Two field experiments were carried out in 2016/2017 and 2017/2018 growing seasons at Farascor county, Damyatta Governorate, to study the effect of the two different intercropping patterns of sugar beet with onion on severity of downy mildew and purple blotch in onion, as well as, Cercospora leaf spot and rust in sugar beet, and on productivity of both crops. Randomized complete blocks design with three replications was used. The area of each plot was $10.5 \mathrm{~m}^{2}$ (3 m length x $3.5 \mathrm{~m}$ width included 4 ridges).

Intercropping patterns:

Two intercropping patterns were used in this investigation and were arranged as follows:

1- Ridge to ridge intercropping pattern:

Ridges in plots were planted alternatively with sown seeds of sugar beet on some ridges and after 20-25 days onion transplants were transplanted on both sides of ridges, $7-10 \mathrm{~cm}$ between hills on other ridges to perform the different intercropping patterns were arranged as follows:

1- Sugar beet was intercropped with onion at rate 1:1 (ridge/ridge).

2- Sugar beet was intercropped with onion at rate 2:2 (ridge/ridge).

3- Sugar beet was intercropped with onion at rate 3:1 (ridge/ridge).

4- Sugar beet was intercropped with onion at rate 1:3 (ridge/ridge).

5- Sole sugar beet plants (sugar beet planted alone).

6- Sole onion plants (onion planted alone).

2- Side to Side of the same ridge intercropping pattern:

Seeds of sugar beet crop (SB) were planted in one side of the ridge and of four ridges then after 20-25 days onion transplants $(\mathrm{ON})$ were transplanted into another

Egypt. J. Phytopathol., Vol. 47, No. 1 (2019) 
side of the ridge to perform the different intercropping patterns were arranged as follows:

1- Intercropping onion on another side of one sugar beet ridge and leaving ridge three without intercropping (1 ridge $\mathrm{ON}+\mathrm{SB}: 3$ ridges $\mathrm{SB}$ alone).

2- Intercropping onion on another side of two sugar beet ridges and leaving two ridges without intercropping ( 2 ridge $\mathrm{ON}+\mathrm{SB}: 2$ ridge $\mathrm{SB}$ alone).

3 - Intercropping onion on another side of three sugar beet ridges and leaving one ridge without intercropping (3 ridge $\mathrm{ON}+\mathrm{SB}$ : 1 ridge $\mathrm{SB}$ alone).

4- Intercropping onion on another side of all sugar beet (4 ridges ON+SB: without ridges SB alone).

5- Sugar beet planted alone of the four ridges on one side of each ridge.

6- Onion planted alone of the four ridges on both sides of each ridge.

Sugar beet seeds (cv. Sultan) were sown during the first week of November in both seasons, while onion seedlings (cv. Giza 20) were transplanted after 20-25 days in both seasons. Agricultural practices (irrigation and fertilization) were practiced as recommended.

Disease severity of onion downy mildew and purple blotch was recorded after three and four months from planting, respectively, according to the method described by Townsend and Heuberger (1943). However, Cercospora leaf spot and rust disease severity values were estimated using modified scale according to Shane and Teng (1992) and modified Cobb's scale (Peterson et al., 1948), respectively at harvest time.

Also, onion bulb yield ( $\mathrm{kg} / \mathrm{plot})$ and sugar beet root yield $(\mathrm{kg} / \mathrm{plot})$ were determined under the different intercropping patterns at harvest and were estimated as expected yield (ton/fed.) of both yield crops.

Land Equivalent Ratio (LER):

Land Equivalent Ratio (LER) was estimated according tom Willey (1979) using the following formula:

Where:

$$
\text { LER }=y a b / y a a+y b a / y b b
$$

Yaa $=$ pure stand yield of species a (onion).

$\mathrm{Ybb}=$ pure stand yield of species $\mathrm{b}$ (sugar beet).

$Y a b=$ mixture yield of $a$ (when combined with $b$ )

$\mathrm{Yba}=$ mixture yield of $\mathrm{b}$ (when combined with $\mathrm{a})$.

Statistical Analysis:

All data were statistically analyzed using analysis of variance (ANOVA) with the Statistical Analysis System MSTAT-C Statistical Packing (Freed 1991). Probabilities equal to or less than 0.05 were considered significant. If ANOVA indicated differences between treatment means LSD test was performed according to Steel and Torrie (1980). 


\section{Results}

I- Effect of two intercropping patterns of onion with sugar beet on onion and sugar beet foliar diseases under field conditions during 2016/2017 and 2017/2018:

\section{1- Ridge to ridge intercropping patterns:}

\section{2- Effect on onion downy mildew or purple blotch disease severity:}

Data shown in Table (1) reveal that all intercropping patterns, i.e. (1:1), (2:2), (1:3) and (3:1) (ridge/ridge) significantly decreased the severity of both downy mildew and purple blotch diseases compared to onion cultivation alone during the two seasons. Intercropping patterns of onion: sugar beet, i.e. (1:3) was the best intercropping pattern in decreasing the severity of both downy mildew and purple blotch diseases, followed by (1:1 alternately) without significant differences between them, however pattern of (2:2), came next in this respect in two successive seasons 2016/2017 and 2017/2018. On the other hand, pattern of onion: sugar beet (1:3) was the least one in decreasing both onion diseases, compared to onion cultivation alone which gave the highest disease severity of both onion foliar diseases in two growing seasons.

Table (1): Effect of intercropping sugar beet with onion by ridge to ridge patterns on downy mildew and purple blotch severity $(\%)$ under field conditions during 2016/ 2017 and 2017/ 2018.

\begin{tabular}{|c|c|c|c|c|c|}
\hline \multicolumn{2}{|c|}{$\begin{array}{c}\text { Intercropping pattern } \\
\text { (ridge/ ridge) }\end{array}$} & $\begin{array}{c}\text { Downy mildew severity } \\
(\%)\end{array}$ & $\begin{array}{c}\text { Purple blotch severity } \\
(\%)\end{array}$ \\
\hline $\begin{array}{c}\text { Sugar beet plants } \\
\text { (SB) }\end{array}$ & $\begin{array}{c}\text { Onion } \\
\text { plants (ON) }\end{array}$ & $2016 / 17$ & $2017 / 18$ & $2016 / 17$ & $2017 / 18$ \\
\hline 1 & 1 & 9.55 & 7.93 & 15.39 & 9.21 \\
\hline 2 & 2 & 15.23 & 12.84 & 18.61 & 14.25 \\
\hline 3 & 1 & 6.48 & 5.39 & 13.28 & 10.94 \\
\hline 1 & 3 & 17.38 & 14.67 & 29.46 & 26.07 \\
\hline \multicolumn{2}{|c|}{ ON alone on four ridges } & 25.19 & 23.54 & 36.19 & 34.72 \\
\hline \multicolumn{2}{|c|}{ SB alone on four ridges } & - & - & - & - \\
\hline \multicolumn{2}{|c|}{ L.S.D. at 0.05 } & 2.853 & 2.635 & 4.098 & 4.024 \\
\hline
\end{tabular}

1.3- Effect on sugar beet Cercospora leaf spot and rust disease severity.

Data in Table (2) show that, generally, all the four intercropping patterns of sugar beet : onion, i.e. (1:1), (2:2), (1:3) and (3:1) (ridge/ridge) significantly reduced disease severity of both Cercospora leaf spot and rust diseases during the two growing seasons compared to the sole sugar beet cultivation. Intercropping pattern (1:3) of sugar beet: onion recorded the least disease severity of both Cercospora leaf spot and rust diseases of sugar beet during the two growing seasons, followed by (1:1 alternately) and (2:2) (ridge/ridge), respectively. On the other hand, the highest percentages of disease severity of the two sugar beet diseases were recorded when

Egypt. J. Phytopathol., Vol. 47, No. 1 (2019) 
sugar beet was cultivated as pure stand plants (sole sugar beet) followed by three ridges of sugar beet altered with one ridge of onion (3:1) intercropping pattern in both seasons.

Table (2): Effect of intercropping sugar beet with onion by ridge to ridge patterns on Cercospora leaf spot and rust disease severity (\%) under field conditions during 2016/2017 and 2017/2018.

\begin{tabular}{|c|c|c|c|c|c|}
\hline \multicolumn{2}{|c|}{$\begin{array}{c}\text { Intercropping pattern } \\
\text { (ridge/ ridge) }\end{array}$} & \multicolumn{2}{c|}{$\begin{array}{c}\text { Cercospora leaf spot } \\
\text { severity (\%) }\end{array}$} & \multicolumn{2}{c|}{ Rust severity (\%) } \\
\hline $\begin{array}{c}\text { Sugar beet } \\
\text { plants (SB) }\end{array}$ & $\begin{array}{c}\text { Onion } \\
\text { plants (ON) }\end{array}$ & $2016 / 17$ & $2017 / 18$ & $2016 / 17$ & $2017 / 18$ \\
\hline 1 & 1 & 9.14 & 8.17 & 11.18 & 9.34 \\
\hline 2 & 2 & 11.55 & 9.81 & 13.73 & 11.08 \\
\hline 3 & 1 & 14.29 & 12.74 & 17.87 & 15.60 \\
\hline 1 & 3 & 7.11 & 5.95 & 9.55 & 7.29 \\
\hline SB alone on four ridges & 16.73 & 15.36 & 19.82 & 17.46 \\
\hline ON alone on four ridges & - & - & - & - \\
\hline \multicolumn{2}{|l|}{ L.S.D. at 0.05 } & 1.901 & 1.734 & 2.271 & 2.013 \\
\hline
\end{tabular}

2. Side to side at the same ridge intercropping patterns:

\section{1- Effect on downy mildew and purple blotch disease severity.}

Data in Table (3) illustrate the effect of four sugar beet (SB) intercropping patterns with onion $(\mathrm{ON})$ arranged by side to side at the same ridge, i.e. (1 ridge $\mathrm{ON}+\mathrm{SB}$ : 3 ridges $\mathrm{SB}$ alone), (2 ridges $\mathrm{ON}+\mathrm{SB}: 2$ ridges $\mathrm{SB}$ alone), (3 ridges $\mathrm{ON}+\mathrm{SB}$ : 1 ridges $\mathrm{SB}$ alone) and (4 ridges $\mathrm{ON}+\mathrm{SB}$ : no ridges with $\mathrm{SB}$ alone) on severity of downy mildew and purple blotch of onion during 2016/2017 and 2017/2018. Generally, all four intercropping patterns of sugar beet: onion (side to side at the same ridge) significantly reduced disease severity of both downy mildew and purple blotch in the two seasons compared to the sole onion plants (cultivated at the two sides of the same ridge). Intercropping patterns, i.e. (1 ridge $\mathrm{ON}+\mathrm{SB}$ : 3 ridges $\mathrm{SB}$ alone) and (2 ridges $\mathrm{ON}+\mathrm{SB}: 2$ ridges $\mathrm{SB}$ alone) were the best significant systems for decreasing both onion foliar diseases in the two growing seasons, followed by intercropping patterns (3 ridges $\mathrm{ON}+\mathrm{SB}$ : 1 ridge $\mathrm{SB}$ alone) and (4 ridges $\mathrm{ON}+\mathrm{SB}$ : no ridges with $\mathrm{SB}$ alone), respectively $\mathrm{On}$ the other hand, the highest percentages of disease severity of the two diseases were recorded when onion was cultivated as pure stand plants (at the two sides / ridge) in the two seasons.

\section{2- Effect on sugar beet Cercospora leaf spot and rust disease severity.}

Data in Table (4) prove that all the sugar beet (SB) intercropping patterns with onion $(\mathrm{ON})$ decreased disease severity of both Cercospora leaf spot and rust diseases of sugar beet in the two growing seasons compared to the sole sugar beet cultivation (cultivated on one side without onion of the four ridges). Intercropping patterns (4 
ridges $\mathrm{ON}+\mathrm{SB}$ : no ridges with $\mathrm{SB}$ alone) recorded the highest significant reduction of severity of both Cercospora leaf spot and rust diseases during the two growing seasons, followed by the intercropping patterns 3 ridge $\mathrm{ON}+\mathrm{SB}$ : 1 ridges $\mathrm{SB}$ alone, 2 ridges $\mathrm{ON}+\mathrm{SB}: 2$ ridges $\mathrm{SB}$ alone and 1 ridge $\mathrm{ON}+\mathrm{SB}: 3$ ridges $\mathrm{SB}$ alone, respectively, which came the next for decreasing of both foliar diseases of sugar beet. On the other hand, the highest percentages of disease severity of the two diseases were recorded when sugar beet was cultivated as pure stand plants (at one side/ ridge) in the two successive seasons.

Table (3): Effect of intercropping sugar beet with onion by side to side at the same ridge patterns on downy mildew and purple blotch severity (\%) under field conditions during 2016/2017 and 2017/2018.

\begin{tabular}{|c|c|c|c|c|c|}
\hline \multicolumn{2}{|c|}{$\begin{array}{c}\text { Intercropping pattern } \\
\text { (side/side at the same ridge) }\end{array}$} & \multicolumn{2}{c|}{$\begin{array}{c}\text { Downy mildew } \\
\text { severity (\%) }\end{array}$} & \multicolumn{2}{c|}{$\begin{array}{c}\text { Purple blotch } \\
\text { severity (\%) }\end{array}$} \\
\hline "SB alone & ON+SB & $2016 / 17$ & $2017 / 18$ & $2016 / 17$ & $2017 / 18$ \\
\hline 3 & 1 & 6.15 & 5.32 & 11.34 & 10.30 \\
\hline 2 & 2 & 7.22 & 6.91 & 12.36 & 11.55 \\
\hline 1 & 3 & 9.18 & 8.47 & 14.43 & 13.87 \\
\hline- & 4 & 12.35 & 11.28 & 17.18 & 15.34 \\
\hline \multicolumn{2}{|c|}{ ON alone on two side of four ridges } & 24.68 & 22.51 & 35.76 & 33.48 \\
\hline SB alone on one side on four ridges & - & - & - & - \\
\hline L.S.D. at 0.05 & 2.668 & 2.437 & 3.754 & 3.514 \\
\hline
\end{tabular}

"SB alone $=$ Sugar beet planted alone on one side of the ridge

** $\mathrm{ON}+\mathrm{SB}=$ Intercropping onion on another side of sugar beet ridge

Table (4): Effect of intercropping sugar beet with onion by side to side at the same ridge patterns on Cercospora leaf spot and rust disease severity (\%) under field conditions during 2016/2017 and 2017/2018.

\begin{tabular}{|c|c|c|c|c|c|}
\hline \multicolumn{2}{|c|}{$\begin{array}{c}\text { Intercropping pattern } \\
\text { (side/side at the same ridge) }\end{array}$} & \multicolumn{2}{c|}{$\begin{array}{c}\text { Cercospora leaf spot } \\
\text { severity }(\%)\end{array}$} & \multicolumn{2}{c|}{ Rust disease (\%) } \\
\hline *SB alone & ${ }^{* *}$ ON+SB & $2016 / 17$ & $2017 / 18$ & $2016 / 17$ & $2017 / 18$ \\
\hline 3 & 1 & 15.32 & 14.85 & 13.27 & 12.56 \\
\hline 2 & 2 & 13.86 & 12.31 & 12.09 & 11.42 \\
\hline 1 & 3 & 11.08 & 10.12 & 10.33 & 10.05 \\
\hline- & 4 & 8.91 & 7.55 & 9.17 & 8.65 \\
\hline SB alone on one side on four ridges & 18.32 & 17.64 & 16.25 & 15.29 \\
\hline ON alone on two side of four ridges & - & - & - & - \\
\hline \multicolumn{2}{|r|}{ L.S.D. at 0.05} & 2.061 & 1.994 & 1.789 & 1.687 \\
\hline
\end{tabular}

${ }^{*}$ SB alone $=$ Sugar beet planted alone on one side of the ridge

${ }^{* *} \mathrm{ON}+\mathrm{SB}=$ Intercropping onion on another side of sugar beet ridge

Egypt. J. Phytopathol., Vol. 47, No. 1 (2019) 
II- Effect of two intercropping patterns of onion with sugar beet on yield productivity of the two crops under field conditions in 2016/2017 and 2017/2018:

1. Ridge to ridge intercropping patterns:

1.1. Effect on onion bulb yield:

Data presented in Table (5) indicate that the associated cropping patterns of onion with sugar beet (as ridge to ridge) on onion bulb yields $\left(\mathrm{kg} / \mathrm{plot}\left(10.5 \mathrm{~m}^{2}\right)\right.$ and expected yield ton/fed.) were increased in all intercropping patterns (ridge onion: ridge sugar beet) compared to onion cultivation alone without significant differences except intercropping pattern (1:3) which decreased onion bulb yield compared to the other patterns in the two seasons 2016/2017 and 2017/2018. Intercropping pattern (ridge onion: ridge sugar beet) ), i.e. (1:1 alternately) recorded the highest onion bulb yield for plot $\left(10.5 \mathrm{~m}^{2}\right)$ and expected yield/fed., followed by pattern (3:1), pattern (2:2) and onion cultivation alone, respectively, However, cropping patterns of (1:3) (ridge onion : ridge sugar beet) significantly decreased onion bulb yield (yield/plot \& expected yield/fed.) compared to onion cultivation alone and the other treatments, where it recorded the least bulb yield during the two growing seasons.

Table (5): Effect of sugar beet with onion by ridge to ridge intercropping patterns on onion bulb yield under natural infection with downy mildew and purple blotch diseases under field conditions in 2016/2017 and 2017/2018.

\begin{tabular}{|c|c|c|c|c|c|}
\hline \multicolumn{2}{|c|}{$\begin{array}{c}\text { Intercropping pattern } \\
\text { (ridge/ ridge) }\end{array}$} & \multicolumn{2}{c|}{$\begin{array}{c}\text { Onion bulb yield } \\
\mathrm{kg} / \mathrm{plot}\left(10.5 \mathrm{~m}^{2}\right)\end{array}$} & \multicolumn{2}{c|}{$\begin{array}{c}\text { Expected onion bulb } \\
\text { yield (ton/fed) }\end{array}$} \\
\hline $\begin{array}{c}\text { Sugar beet plants } \\
\text { (SB) }\end{array}$ & $\begin{array}{c}\text { Onion } \\
\text { plants (ON) }\end{array}$ & $2016 / 17$ & $2017 / 18$ & $2016 / 17$ & $2017 / 18$ \\
\hline 1 & 1 & 25.61 & 26.24 & 10.24 & 10.50 \\
\hline 2 & 2 & 23.77 & 24.82 & 9.51 & 9.93 \\
\hline 3 & 1 & 21.69 & 22.95 & 8.68 & 9.18 \\
\hline 1 & 3 & 24.86 & 25.37 & 9.94 & 10.15 \\
\hline \multicolumn{2}{|c|}{ ON alone on four ridges } & 23.56 & 23.99 & 9.42 & 9.60 \\
\hline \multicolumn{2}{|r|}{ SB alone on four ridges } & - & - & - & - \\
\hline \multicolumn{2}{|r|}{ L.S.D. at 0.05 } & 3.166 & 3.260 & 1.267 & 1.304 \\
\hline
\end{tabular}

\subsection{Effect on sugar beet yield:}

Data in Table (6) show that all associated cropping patterns of sugar beet with onion (as ridge to ridge) increased root yield of sugar beet $\left(\mathrm{kg} / \mathrm{plot}\left(10.5 \mathrm{~m}^{2}\right) \&\right.$ expected root yield ton/fed.) compared to sugar beet cultivated alone without obvious significant differences between them except pattern of (1:1 alternately) in the two seasons. Intercropping pattern (ridge sugar beet: ridge onion), i.e. (1:1 alternately) recorded the highest significant sugar beet root yield $(\mathrm{kg} / \mathrm{plot}$ and expected root yield ton/fed.), followed by cropping patterns (3:1) and (2:2), 
respectively without significant differences between them, However, cropping pattern of (1:3) and sugar beet cultivation alone recorded the least significant root yield of sugar beet for yield/plot and expected yield/fed., without significant differences between each other in the two growing seasons.

Table (6): Effect of sugar beet with onion by ridge to ridge intercropping patterns on sugar beet root yield under natural infection with Cercospora leaf spot and rust diseases under field conditions during 2016/2017 and 2017/2018 seasons.

\begin{tabular}{|c|c|c|c|c|c|}
\hline \multicolumn{2}{|c|}{$\begin{array}{c}\text { Intercropping pattern } \\
\text { (ridge/ ridge) }\end{array}$} & \multicolumn{2}{c|}{$\begin{array}{c}\text { Root yield } \\
\left(\mathrm{Kg} / \mathrm{plot} 10.5 \mathrm{~m}^{2}\right)\end{array}$} & \multicolumn{2}{c|}{$\begin{array}{c}\text { Expected root yield } \\
\text { (ton/fed) }\end{array}$} \\
\hline $\begin{array}{c}\text { Sugar beet } \\
\text { plants (SB) }\end{array}$ & $\begin{array}{c}\text { Onion } \\
\text { plants (ON) }\end{array}$ & $2016 / 17$ & $2017 / 18$ & $2016 / 17$ & $2017 / 18$ \\
\hline 1 & 1 & 58.70 & 61.38 & 23.48 & 24.55 \\
\hline 2 & 2 & 55.33 & 58.03 & 22.13 & 23.21 \\
\hline 3 & 1 & 55.88 & 55.45 & 22.35 & 22.18 \\
\hline 1 & 3 & 50.90 & 53.23 & 20.36 & 21.29 \\
\hline \multicolumn{2}{|c|}{ SB alone on four ridges } & 49.45 & 51.68 & 19.78 & 20.67 \\
\hline \multicolumn{2}{|c|}{ ON alone on four ridges } & - & - & - & - \\
\hline \multicolumn{2}{|r|}{ L.S.D. at 0.05 } & 7.180 & 7.430 & 2.872 & 2.972 \\
\hline
\end{tabular}

2. Side to side at the same ridge intercropping patterns:

\subsection{Effect on onion bulb yield:}

The effect of different four intercropping patterns of sugar beet (SB) arranged with onion $(\mathrm{ON})$ by side to side at the same ridge, i.e. (1 ridge $\mathrm{ON}+\mathrm{SB}: 3$ ridges $\mathrm{SB}$ alone), ( 2 ridges $\mathrm{ON}+\mathrm{SB}: 2$ ridges $\mathrm{SB}$ alone), (3 ridge $\mathrm{ON}+\mathrm{SB}: 1$ ridges $\mathrm{SB}$ alone) and (4 ridges $\mathrm{ON}+\mathrm{SB}$ : no ridges with $\mathrm{SB}$ alone) on onion bulb yields $(\mathrm{kg} / \mathrm{plot}(10.5$ $\mathrm{m}^{2}$ ) and expected yield ton/fed.) was investigated (Table 7). Tabulated data illustrate that all intercropping patterns increased onion bulb yields compared to onion planted alone on two sides of the four ridges without significant differences between them except cropping pattern (1 ridge $\mathrm{ON}+\mathrm{SB}: 3$ ridges $\mathrm{SB}$ alone) during the two growing seasons 2016/2017 and 2017/2018. Intercropping patterns, i.e. (3 ridges ON+SB: 1 ridge $\mathrm{SB}$ alone) recorded the highest onion bulb yield for plot $\left(10.5 \mathrm{~m}^{2}\right)$ and expected yield/fed., followed by patterns (4 ridges $\mathrm{ON}+\mathrm{SB}$ : no ridges with $\mathrm{SB}$ alone), (2 ridges $\mathrm{ON}+\mathrm{SB}: 2$ ridges $\mathrm{SB}$ alone) and onion cultivated as two sides alone, respectively. However, pattern (1 ridge $\mathrm{ON}+\mathrm{SB}: 3$ ridges $\mathrm{SB}$ alone) gave the least significant onion bulb yields during the two growing seasons.

\subsection{Effect on sugar beet yield:}

Data shown in Table (8) reveal that all the four sugar beet (SB) intercropping patterns with onion $(\mathrm{ON})$ arranged by side to side at the same ridge i.e. (1 ridge $\mathrm{ON}+\mathrm{SB}: 3$ ridges $\mathrm{SB}$ alone), (2 ridges $\mathrm{ON}+\mathrm{SB}: 2$ ridges $\mathrm{SB}$ alone), (3 ridges $\mathrm{ON}+\mathrm{SB}$ : 1 ridge $\mathrm{SB}$ alone) and (4 ridges $\mathrm{ON}+\mathrm{SB}$ : no ridges with $\mathrm{SB}$ alone) Egypt. J. Phytopathol., Vol. 47, No. 1 (2019) 
significantly increased root yield of sugar beet without obvious significant differences between them compared to sugar beet planted alone on one side of the four ridges. Intercropping pattern, i.e. (1 ridge $\mathrm{ON}+\mathrm{SB}$ : 3 ridges $\mathrm{SB}$ alone) was the superior pattern that gave the highest root yield of sugar beet, followed by cropping patterns, (2ridge $\mathrm{ON}+\mathrm{SB}$ : 2ridges $\mathrm{SB}$ alone), (3 ridge3 $\mathrm{ON}+\mathrm{SB}$ : 1 ridge $\mathrm{SB}$ alone) and (4 ridges planted with SB alone). Meanwhile, sugar beet cultivated alone recorded the least significant sugar beet root yield for yield/plot and expected yield/fed., during the two growing seasons.

Table (7): Effect of sugar beet with onion by side to side of the same ridge intercropping patterns on onion bulb yield under natural infection with downy mildew and purple blotch diseases under field conditions in 2016/2017 and 2017/2018.

\begin{tabular}{|c|c|c|c|c|c|}
\hline \multicolumn{2}{|c|}{$\begin{array}{c}\text { Intercropping pattern } \\
\text { (side/side at the same ridge) }\end{array}$} & \multicolumn{2}{|c|}{$\begin{array}{l}\text { Onion bulb yield } \\
\mathrm{kg} / \text { plot }\left(10.5 \mathrm{~m}^{2}\right)\end{array}$} & \multicolumn{2}{|c|}{$\begin{array}{l}\text { Expected onion bulb } \\
\text { yield (ton/fed) }\end{array}$} \\
\hline *SB alone & **N+SB & $2016 / 17$ & $2017 / 18$ & $2016 / 17$ & $2017 / 18$ \\
\hline 3 & 1 & 22.42 & 23.11 & 8.97 & 9.24 \\
\hline 2 & 2 & 25.38 & 26.04 & 10.15 & 10.42 \\
\hline 1 & 3 & 26.95 & 27.69 & 10.78 & 11.08 \\
\hline- & 4 & 26.77 & 27.24 & 10.71 & 10.90 \\
\hline \multicolumn{2}{|c|}{ ON alone on two side of four ridges } & 24.65 & 25.47 & 9.86 & 10.19 \\
\hline \multicolumn{2}{|c|}{ SB alone on one side on four ridges } & - & - & - & - \\
\hline \multicolumn{2}{|c|}{ L.S.D. at 0.05} & 3.355 & 3.441 & 1.343 & 1.377 \\
\hline
\end{tabular}

${ }^{*} \mathrm{SB}$ alone $=$ Sugar beet planted alone on one side of the ridge

${ }^{* *} \mathrm{ON}+\mathrm{SB}=$ Intercropping onion on another side of sugar beet ridge

Table (8): Effect of sugar beet with onion by side to side of the same ridge intercropping system on sugar beet root yield under natural infection with Cercospora leaf spot and rust diseases under field in 2016/2017 and 2017/2018.

\begin{tabular}{|c|c|c|c|c|c|}
\hline \multicolumn{2}{|c|}{$\begin{array}{l}\text { Intercropping system side/side } \\
\text { (of the same ridge) }\end{array}$} & \multicolumn{2}{|c|}{$\begin{array}{c}\text { Root yield } \\
\left(\mathrm{Kg} / \text { plot } 10.5 \mathrm{~m}^{2}\right)\end{array}$} & \multicolumn{2}{|c|}{$\begin{array}{c}\text { Expected root yield } \\
\text { (ton/fed) }\end{array}$} \\
\hline${ }^{*}$ SB alone & $\mathrm{ON}+\mathrm{SB}$ & $2016 / 17$ & $2017 / 18$ & $2016 / 17$ & $2017 / 18$ \\
\hline 3 & 1 & 64.53 & 65.38 & 25.81 & 26.15 \\
\hline 2 & 2 & 62.45 & 63.35 & 24.98 & 25.34 \\
\hline 1 & 3 & 60.35 & 61.70 & 24.14 & 24.68 \\
\hline- & 4 & 59.48 & 60.15 & 23.79 & 24.06 \\
\hline \multicolumn{2}{|c|}{ SB alone on one side on four ridges } & 50.20 & 52.13 & 20.08 & 20.85 \\
\hline \multicolumn{2}{|c|}{ ON alone on two side of four ridges } & - & - & - & - \\
\hline \multicolumn{2}{|c|}{ L.S.D. at 0.05} & 7.958 & 8.083 & 3.183 & 3.233 \\
\hline
\end{tabular}

SB alone $=$ Sugar beet planted alone on one side of the ridge

${ }^{* *} \mathrm{ON}+\mathrm{SB}=$ Intercropping onion on another side of sugar beet ridge 
III- Effect of two intercropping patterns of onion with sugar beet on land equivalent ratio (LER) under field conditions during 2016/2017 and 2017/2018 seasons:

1. Ridge to ridge intercropping patterns:

Results in Table (9) show that all intercropping patterns (ridge/ ridge) of onion with sugar beet increased land equivalent ratio (LER) in the two seasons. The values of land equivalent ratio for intercropping treatments were significantly greater than the monoculture of either onion or sugar beet (1.0). Regarding for land equivalent ratio of both onion (LON) and sugar beet (LSB), all the intercropping patterns increased LON compared to sole onion cultivation except pattern (three ridges SB: one ridge $\mathrm{ON}$ ) which decreased LON compared to onion planted alone, however, all intercropping patterns increased LSB and superior than sugar beet cultivated alone. On the other hand, Intercropping pattern, i.e. (1:1 ridge alternately) recorded the highest values for (LER) in the two growing seasons, followed by (2:2), and (one SB: three ON) while the lowest LER value was obtained with pattern 3 SB: one ridge $\mathrm{ON}$.

Table (9): Effect of sugar beet with onion by ridge to ridge intercropping patterns on land equivalent ratio (LER) under natural infection with onion and sugar beet diseases under field conditions in 2016/2017 and 2017/2018.

\begin{tabular}{|c|c|c|c|c|c|c|c|}
\hline $\begin{array}{c}\text { Intercropping patterns } \\
\text { (ridge/ ridge) }\end{array}$ & \multicolumn{3}{|c|}{$\begin{array}{c}\text { Land equivalent ratio 2016/ } \\
\text { 2017 LON + LSB =LER }\end{array}$} & \multicolumn{2}{c|}{$\begin{array}{c}\text { Land equivalent ratio 2017/ } \\
\text { 2018 LON + LSB =LER }\end{array}$} \\
\hline SB & ON & LON & LSB & LER & LON & LSB & LER \\
\hline 1 & 1 & 1.09 & 1.19 & 2.28 & 1.09 & 1.19 & 2.28 \\
\hline 2 & 2 & 1.01 & 1.12 & 2.13 & 1.03 & 1.12 & 2.15 \\
\hline 3 & 1 & 0.92 & 1.13 & 2.05 & 0.96 & 1.07 & 2.03 \\
\hline 1 & 3 & 1.06 & 1.03 & 2.09 & 1.06 & 1.03 & 2.09 \\
\hline \multicolumn{2}{|r|}{ L.S.D. at 0.05} & 0.031 & 0.028 & 0.046 & 0.023 & 0.030 & 0.046 \\
\hline
\end{tabular}

2. Side to side at the same ridge intercropping patterns:

Data in Table (10) indicate that all four sugar beet (SB) intercropping patterns with onion $(\mathrm{ON})$ arranged by side to side at the same ridge (1 ridge $\mathrm{ON}+\mathrm{SB}$ : 3 ridges $\mathrm{SB}$ alone), (2 ridges $\mathrm{ON}+\mathrm{SB}: 2$ ridges $\mathrm{SB}$ alone), (3 ridges $\mathrm{ON}+\mathrm{SB}: 1$ ridge $\mathrm{SB}$ alone) and (4 ridges $\mathrm{ON}+\mathrm{SB}$ : no ridges with $\mathrm{SB}$ alone) significantly increased land equivalent ratio (LER) during the two seasons in comparison with monoculture of each crop (1.0). The values of land equivalent ratio (LER) for all intercropping patterns (side/ side) were significantly greater than cultivation of either onion or sugar beet alone. With concern to land equivalent ratio of both onion (LON) and sugar beet (LSB), all intercropping patterns (side/ side) increased LON compared to onion planted alone except one ridge $\mathrm{ON}+\mathrm{SB}$ : three ridge $\mathrm{SB}$ alone which significantly decreased LON compared to monoculture of onion plants in the two

Egypt. J. Phytopathol., Vol. 47, No. 1 (2019) 
growing seasons. However, all the intercropping patterns increased LSB which was superior to sugar beet cultivated alone. On the other hand, the highest values of LER were obtained with intercropping patterns, i.e. (3 ridges $\mathrm{ON}+\mathrm{SB}: 1$ ridge $\mathrm{SB}$ alone), 2 ridges $\mathrm{ON}+\mathrm{SB}$ : 2 ridges $\mathrm{SB}$ alone) and (4 ridges $\mathrm{ON}+\mathrm{SB}$ : no ridges with $\mathrm{SB}$ alone), respectively. Meanwhile, the lowest LER value was recorded with patterns, 1 ridge $\mathrm{ON}+\mathrm{SB}: 3$ ridges $\mathrm{SB}$ alone.

Table (10): Effect of sugar beet with onion by side to side of the same ridge intercropping patterns on Land equivalent ratio (LER) under natural infection with onion and sugar beet diseases under field conditions in 2016/2017 and 2017/2018.

\begin{tabular}{|c|c|c|c|c|c|c|c|}
\hline $\begin{array}{c}\text { Intercropping patterns } \\
\text { side/ side (of the same } \\
\text { ridge) }\end{array}$ & \multicolumn{3}{c|}{$\begin{array}{c}\text { Land equivalent ratio } \\
2016 / 2017 \text { LON + LSB } \\
\text { =LER }\end{array}$} & \multicolumn{3}{c|}{$\begin{array}{c}\text { Land equivalent ratio } \\
\text { 2017/ 2018 LON + LSB } \\
\text { =LER }\end{array}$} \\
\hline${ }^{*}$ SB alone & ${ }^{* *}$ ON+SB & LON & LSB & LER & LON & LSB & LER \\
\hline 3 & 1 & 0.91 & 1.29 & 2.20 & 0.91 & 1.25 & 2.16 \\
\hline 2 & 2 & 1.03 & 1.24 & 2.27 & 1.02 & 1.22 & 2.24 \\
\hline 1 & 3 & 1.09 & 1.20 & 2.29 & 1.09 & 1.18 & 2.27 \\
\hline- & 4 & 1.09 & 1.18 & 2.27 & 1.07 & 1.15 & 2.22 \\
\hline \multicolumn{2}{|r|}{ L.S.D. at 0.05} & 0.033 & 0.019 & 0.017 & 0.033 & 0.016 & 0.022 \\
\hline
\end{tabular}

Discus sion

The limitation of the Egyptian land led to an increase need to maximize land usage to enhance farmer's income. Intercropping of different crop species can be used as strategy to increase the amount of diversity within an individual field (Boudreau and Mundt, 1997). Also, the purpose of intercropping is to generate beneficial biological interactions between the crops. Intercropping can increase yields, more efficiently use available resources, reduce weed, insect and disease pressures and provide greater biological and economic stability (Vandermeer, 1989). The incidence of disease is often less in mixed planting than in monocultures because the distance between similar plants is greater than in more intensive growing systems, so is less likely that propagles or vectors of pathogens will successfully move from one host to another.

Regarding to the effect of ridge to ridge intercropping patterns of onion (ON) intercropped with sugar beet (SB) on foliar diseases of both crops, all intercropping patterns, i.e. (1:1), (2:2), (1:3) and (3:1) (ON ridge/ridge SB) significantly decreased disease severity of both downy mildew and purple blotch of onion, as well as, Cercospora leaf spot and rust diseases of sugar beet during the two seasons 2016/2017 and 2017/2018 compared to monoculture cultivation of each crop. Intercropping patterns of onion: sugar beet (1 ridge ON: 3 ridges $\mathrm{SB}$ ) and (1ON: 
1SB alternately) were the most superior intercropping patterns in decreasing disease severity of both onion downy mildew and purple blotch diseases. However, intercropping pattern ( 3 ridges $\mathrm{ON}: 1$ ridge $\mathrm{SB}$ ) and (1ON: 1SB alternately) were the most effective patterns for decreasing both Cercospora leaf spot and rust diseases of sugar beet during the two growing seasons. On the other hand, intercropping patterns onion $(\mathrm{ON})$ with sugar beet arranged by side to side, (1 ridge $\mathrm{ON}+\mathrm{SB}: 3$ ridges $\mathrm{SB}$ alone) and (2 ridges $\mathrm{ON}+\mathrm{SB}: 2$ ridges $\mathrm{SB}$ alone) were the best patterns for decreasing both onion foliar diseases, meanwhile, intercropping patterns (4 ridges $\mathrm{ON}+\mathrm{SB}$ : no ridges with $\mathrm{SB}$ alone) and (3 ridges $\mathrm{ON}+\mathrm{SB}: 1$ ridges $\mathrm{SB}$ alone were the most superior ones for reducing severity of both Cercospora leaf spot and rust diseases during the two seasons. The highest severity of the four tested foliar diseases of the two different intercropping patterns were recorded when either onion or sugar beet was cultivated alone in both seasons. The obtained results are in agreement with those obtained by Corazza et al. (1993) and Lamey, (1997). Ismail et al. (2005) who stated that disease severity of Cercospora leaf spot was significantly decreased by the (2:2) intercropping systems or (3:1) (row/row) as sugar beet: faba bean compared with the pure stand and the other systems. Moreover, the great reduction of both faba bean chocolate spot and rust diseases was observed under $(1: 1)$ or $(3: 1)$ patterns as sugar beet: faba been. Otherwise, disease severity was increased in pure stand of both tested crops. El Mansoub et al., 2010 found that disease severity\% of Cercospora leaf spot and rust was affected by (sugar beet: garlic) (row/row) intercropping systems that gave the great reduction in these diseases compared to sole sugar beet.

Several investigators have reported the effect of intercropping on decreased foliar diseases of onion. Narla et al 2011 studied the effectiveness of vegetable intercrops, i.e. carrot, spider plant and French bean in the management of downy mildew (Peronospora destrutor) and purple blotch (Alternaria porri) of bulb onion and revealed that the tested vegetable intercrops significantly reduced downy mildew and purple blotch severity but had no significant effect on disease incidence. Spider plant (Chlorophytum comosum) was the most effective vegetable intercrop in reducing downy mildew severity by up to $21 \%$ and purple blotch severity by $18 \%$. Also, Galande and Simon (2019) demonstrated that legume intercrops were effective in reducing purple blotch on onion and found that French bean was the most effective legume intercrop in reducing purple blotch incidence by up to $49.1 \%$.

The reduction in disease severity of either downy mildew and purple blotch diseases of onion or Cercospora leaf spot and rust of sugar beet may be attributed to that planting onion or sugar beet alternatively might have decreased the relative humidity between plants, and hence reduced spores germination and decreased probability of fungal spores to encounter onion or sugar beet plants. Otherwise, increased disease severity in crops growing alone may be due to possible increase of relative humidity and planting dense which are favorable for germination of spores and developing of diseases (Gantiry et al., 1993 and Garrett and Mundt, 1999).

Egypt. J. Phytopathol., Vol. 47, No. 1 (2019) 
Studies by Ramert and Lennartsson (2002) have indicated that intercropping reduces the proportion of susceptible host tissues and, therefore, impacting on the production, amount and efficiency of the disease inoculum and, therefore, limiting spread and development of the disease. In addition, intercropping increases the space between the rows of onion and sugar beet plants, resulting in greater distance to be travelled by the disease inocula. Further, the two tested intercrops may have created a physical barrier that intercepted or filtered the fungal propagules, thus effectively limiting dissemination of the pathogen. Beuerlein, (2005) stated that multiple cropping drastically reduces the elapsed time between successive crops and therefore can greatly increase the disease pressure for both crops. Where intense multiple cropping is practiced, the beneficial effects of crop rotation (weed, insect, and disease control) are totally negated. Song et al., (2007) show that intercropping has significant effects on microbiological and chemical properties in the rhizosphere, which may contribute to the yield enhancement by intercropping.

The present results showed clearly that yield of onion and sugar beet was significantly maximized by the two intercropping patterns with some exception compared to onion or sugar beet cultivation alone in the two seasons. The most superior pattern of (ridge onion: ridge sugar beet) was 1ON:1 SB alternately, followed by pattern $3 \mathrm{ON}$ : $1 \mathrm{SB}$ (for onion yield) or $1 \mathrm{ON}: 3 \mathrm{SB}$ (for sugar beet yield). However, the most superior patterns of intercropping pattern (side to side at the same ridge) were 3 ridges $\mathrm{ON}+\mathrm{SB}$ : 1 ridge $\mathrm{SB}$ alone and all four ridges planted $\mathrm{ON}+\mathrm{SB}$ side to side. On the other side, intercropping pattern 1 ridge $\mathrm{ON}+\mathrm{SB}$ : 3 ridges SB alone was the superior pattern that gave the highest root yield of sugar beet. Similar results were obtained by Farag, (1990). Sugar beet and faba bean intercropping significantly increased yield components of both crops and quality traits of sugar beet particularly for the (2:2 and 3:1) intercropping systems for sugar beet compared with the other intercropping systems (Ismail et al., 2005). El Mansoub et al, (2010) showed that yield and yield components as well as juice quality of sugar beet were significantly affected by intercropping system with (sugar beet : faba bean) or (sugar beet : garlic).

Disagreement results were obtained with many investigators (Amer et al., 1997). Marey (2004) reported that intercropping sugar beet with faba been and chick pea resulted in a significant decrease in root yield ton/fed, as compared to monoculture. Farghaly et al. (2003) found that sugar beet yield and quality were decreased by intercropping with faba bean compared with pure stand. Faba bean yield and yield components were reduced by intercropping. They were higher in wider than in narrower ridges. The intercropping is recommended to be a common practice for maximizing unit area productivity and reducing yield losses due to pests and diseases per unit area Omar et al, (1993). Abdel Motagally and Metwally, (2014), indicated that sugar beet yield and its components were not significantly decreased by intercropping with onion comparing with pure stand, meanwhile, the associated cropping patterns of onion with sugar beet on yield and its components were 
significantly decreased by intercropping. Also, Galande and Simon (2019) demonstrated that intercropping onion with the vegetable reduced both total and marketable bulb yield. These results may be due to competition between sugar beet and onion plants for nutrient, water and solar radiation.

Our results in this study indicated that the values of land equivalent ratio (LER) of the two intercropping patterns of onion $(\mathrm{ON})$ with sugar beet $(\mathrm{SB})$, i.e. (ON ridge: ridge $\mathrm{SB}$ ) and (side to side at the same ridge "ON+SB ridge: ridge $\mathrm{SB}$ alone") were significantly greater than monoculture of either onion or sugar beet. Intercropping pattern of (ON ridge: ridge $\mathrm{SB}),(1: 1$ ridge alternately) recorded the highest values for (LER) during the two growing seasons, followed by (2:2), and (3 SB: one ridge ON), while the lowest LER value was obtained with pattern (one SB: three ON). On the other hand, the highest values of LER of $(\mathrm{ON}+\mathrm{SB}$ ridge: ridge $\mathrm{SB}$ alone) were recorded by patterns i.e. (3 ridges $\mathrm{ON}+\mathrm{SB}$ : 1 ridge $\mathrm{SB}$ alone), 2 ridges $\mathrm{ON}+\mathrm{SB}: 2$ ridges $\mathrm{SB}$ alone) and (4 ridges $\mathrm{ON}+\mathrm{SB}$ : no ridges with $\mathrm{SB}$ alone), respectively, meanwhile, the lowest LER value was recorded with pattern (1 ridge ON+SB: 3 ridges $\mathrm{SB}$ alone) in this respect. The obtained results are in agreement with several investigators. Farghaly et al., 2003, showed that the highest values for LER were observed when intercropping sugar beet with onion, while the lowest values were done when intercropping sugar beet with faba bean. Ismail et al., 2005 cleared that LER of (1:1) and (1:3) systems of (sugar beet: faba been) was advantageous in the first and second seasons, respectively. Abou Khadra et al. (2013) showed that land equivalent ratio (LER) values were greater than one at any intercropping systems of wheat with sugar beet. Abdel Motagally and Metwally, (2014) indicated that intercropping onion with sugar beet increased land equivalent ratio in all intercropping patterns compared to each crop planted alone.

\section{Conclusions}

Data of the present study indicated that intercropping of the two evaluated intercropping patterns of onion with sugar beet was found as a good treatment to minimize disease severity of downy mildew and purple blotch diseases of onion, as well as Cercospora leaf spot and rust diseases of sugar beet. In addition, maximizing yield production of onion bulb and sugar beet root yield, as well as, increasing land equivalent ratio (LER) of the two intercropping patterns compared to each crop cultivated alone. Since chemicals have many hazardous effects on the environment as well as on the persons who handle them during application in the field and consumers using the product, so used of intercropping system under field conditions would be considered as better, as it is beneficial and eco-friendly.

\section{Ref ere nces}

Abdel-Megid, M.S.; Metwally, A.H.; Abdel-Momen, S.M. and Hilal, A.A. 2001. A preliminary field study on the possibility of controlling foliar diseases of onion

Egypt. J. Phytopathol., Vol. 47, No. 1 (2019) 
using some Egyptian medicinal plant extracts in comparison with a fungicide. Egypt. J. Phytopathol., 29(1): 21-31.

Abdel Motagally, F.M. and Metwally, A.K. 2014. Maximizing productivity by intercropping onion on sugar beet. Asian Journal of Crop Science, 6: 226-235.

Abou Khadra, S.H.; Badwy, S.A.E.; Salah, E.A.T. and Dina, E.E.E. 2013. Effect of intercropping wheat with sugar beet on their productivity and land use. J. Agric. Res. Kafr El-Sheikh Univ., 39: 37-53.

Ahmed, S.E.; Abou-Salama, A.M.; El-Naggar, G.R. and Abdel-Motagally, F.M.F. 2009. Studies on legume-black cumin intercropping. Egypt. J. Appl. Sci., 24: 553-563.

Ali, N.S. and Albayati D.H.M. 2018. The role of broad bean and onion intercropping on productivity of both crops and nitrogen budget in soil. The Iraqi Journal of Agricultural Sciences, 49(1): 21-26.

Amer, M.I.; Radi, M.M.; Ali, K.A. and Zalat, S.S. 1997. Intercropping faba bean with sugar beet under different plant densities. Egypt J. Appl. Sci., 12(1): 155161.

Anonymous, 2017, Economic Affairs Sector, Ministry of Agriculture, Egypt.

Anonymous, 2019. Annual Report of the Central Council for Sugar Crops. Ministry of Agric. and Land Reclamation, Egypt (In Arabic).

Ata, A.A., 2005. Studies on Sugar Beet Rust Disease in Egypt. M. Sc. Thesis, Plant Path. Dept., Fac. of Agric., Ain Shams Univ. Egypt. pp 22-25.

Ata, A.A.; El-Samman, M.G.; Moursy, M.A. and Mostafa, M.H. 2005. Effect of rust infection on sugar beet yield components. Egyptian J. Agric. Res., 83(1): 11-19.

Ata, A.A., 2014. Influence of Cercospora leaf spot on sugar beet yield components in Egypt. Egypt J. Phytopathol., 42(1): 11-24.

Badawy, S.A.E. and Shalaby G.A. 2015. Effect of intercropping of sugar beet with onion and garlic on insect infestation, sugar beet yield and economics. J. Plant Production, Mansoura Univ., 6(6): 903-914.

Beuerlein, J. 2005. Multiple Cropping. Chapter 8: in Ohio Agronomy Guide, $14^{\text {th }}$ Edition, Bulletin 472-05.

Boudreau, M.A. and Mundt, C.C. 1997. Ecological approaches to disease control. p. 33-62. In N.A. Rechcigl and J.E. Rechcigl (ed.) Environmentally safe approaches to crop disease control. CRC Press LLC, Boca Raton. 
Corazza, L.; Chilosi, G. and Baalmas, V. 1993. Relationship between different types of intercropping systems and the development of pathogenic fungi. Agricoltura Ricerca., 15: 151-262.

El-Fiki, A.I.I.; Mohamed, F.G. and El-Mansoub, M.M.A. 2007. Studies on sugar beet rust disease in Egypt. I: Disease control and some vital activities affected by infected sugar beet plants grown under greenhouse conditions. Proc. $11^{\text {th }}$ Cong. Egypt. Phytopathol. Soc., November 2007, Giza, Egypt.

El-Mansoub, M.M.A.; Eman, M.; Abdel-Fattah, M. and Ibrahim, M.M.A. 2017. Efficiency of some biocides as safe alternatives to fungicides on Cercospora leaf spot control, their effect on biochemical constituent and yield of sugar beet. Egypt. J. Phytopathol., 45(2): 145-164.

El-Mansoub, M.M.A.; Hussein, M.Y. and Khalifa, M.M.A. 2010. Effect of some intercropping systems of faba bean and garlic with sugar beet on severity of sugar beet Cercospora leaf spot and rust diseases and its yield and quality. Egypt .J. of Appl. Sci., 25(9): 421-436.

El Refaey R.A.; Abd-El Razek U.A.; Sherief M.N. and Shehata, M.A.K.Z. 2018. Influences of ridge width and intercropping onion with faba bean on bulb yield and competitive relationships. Journal of Environmental Studies and Researches, 6(E2): 157-182.

Farag, M.H. 1990. Effect of Intercropping Faba bean with Sugar Beet. M. Sc. Thesis, Fac. Agric. Al-Azhar Univ.pp145.

Farghaly, B.S.; Zohry, A.A. and Bassal, S.A. 2003. Crops management for intercropping sugar beet with some essential crops to maximize area unit productivity. J. Agric. Sci. Mansoura Univ., 28(7): 5183-8199.

Freed, R.D. 1991. A Software Program for the Design, Management and Analysis of Agronomic Research Experiments. Michigan State University, USA. p. 400.

Gadallah, R.E.; Abdel-Galil, A.M. and Nawar, F.R. 2006. Maximizing productivity by intercropping some winter crops on sugar beet. J. Agric. Sci. Mansoura Univ., 31: 2601-2614.

Galande D.R. and Simon, S. 2019. Effect of Intercropping on Purple Blotch (Alternaria porri) of Onion (Allium cepa L.). Int. J. Curr. Microbiol. App. Sci., 8(02): 1105-1111.

Gantiry, S.M.; Salem, D.E.; Hassanin, A.M. and Abd El-Kader, M.A. 1993. Effect of intercropping soybean-maize on fungal disease and yield. Egypt J. Appl. Sci., 8(5): 518-527.

Egypt. J. Phytopathol., Vol. 47, No. 1 (2019) 
Gao, Y.; Wu, P.T.; Zhao, X.N. and Wang, Z.K. 2014. Growth, yield, and nitrogen use in the wheat/maize intercropping system in an arid region in north western China. Field Crop Research, 167: 19-30.

Garrett, K.A. and Mundt, C.C. 1999. Epidemiology in mixed host populations. Phytopathology, 89: 984-990.

Getahun D.; Getaneh M. and Habte B. 2018. Companion crops for intercropping with onion production in the dry Season at Fogera District of South Gondar Zone in Ethiopia. International J. of Res. Studies in Agric. Sci. (IJRSAS) 4:(4) 17-24.

Gupta, R.B.L. and Pathak, V.N. 1988. Yield losses in onions due to purple leaf blotch disease caused by Alternaria porri. Phytophylactica, 20: 21-23.

Hoffmann, M.P.; Petzoldt, C.H. and Frodsham, A.C. 1996. Integrated Pest Management for Onions. New York State IPM Program Publication: 119-78 pp.

Ismail, A.M.A.; Manal, Y.H. and Saieda, S.A. 2005. Effect of intercropping Faba bean with sugar beet on some foliar diseases and its relation with yield and its components. Egypt. J. Appl. Sci., 20(10a): 165-182.

Javadzadeh, A.; Ghorbanihagho, A.; Bonyadi, S.; Rashidi, M. R.; Mesgari, M.; Rashtchizadeh, N. and Argani, H. 2009. Preventaion effect of onion juice on selenite-induced experimental cataract. Ind. J. Ophthalmol., 57: 185-189.

Kumar, P.T. 2007. Biological Management of Alternaria Blight of Onion. M.Sc. College of Agriculture, Dharwad University of Agricultural Sciences, Dharwad. $112 \mathrm{pp}$.

Kumar, B.; Tiwana, U.S.; Singh, A. and Ram, H. 2014. Productivity and quality of intercropped maize (Zea mays L.) + cowpea [Vigna unguiculata (L.) Walp.] fodder as influenced by nitrogen and phosphorus levels. Range Management and Agroforestry, 35: 263-267.

Lakra, B.S. 1999. Development of purple blotch incited by Alternaria porri and its losses in seed crop of onion (Allium cepa). Indian J. Agric. Sci., 69(2): 144-146.

Lamey, A. 1997. Sugar beet disease control. Sugar beet Research and Extension Reports, 28: 269-272.

Mahmoud, N.A.; Khalifa, M.M.A. and Abou-Zeid, N.M. 2013. Performance of some biofungicides on the most onion economic diseases compared to recommended fungicide in Egypt. II- Downy mildew and purple blotch diseases control and their economical feasibility. Egypt .J. of Appl. Sci., 28(1): 66-92.

Marey, R.A. 2004. Effect of Intercropping Faba Been and Chick Pea on Sugar Beet. Ph.D. Thesis, Dept. Agronomy Fac. Agric. Assiut, Univ. 119. 
Narla, Rama.; Muthomi, J.W.; Gachu, S.M.; John, H. and Olubayo, F. 2011. Effect of intercropping bulb onion and vegetables on purple blotch and downy mildew. Journal of Biological Sciences, 11: 52-57.

Omar, S.A.; Rahhal, M.M.; Hilal, A.A. and Zayed, A. 1993. Influence of intercropping of broad bean with some medicinal plants on disease severity of chocolate spot and rust diseases and seed yield. $4^{\text {th }}$ Conf. Agri. Dev. Ain Shams Univ. Cairo Annals. Agric. Sci., Sp. Issue, 2, 551-560.

Peterson, R.F.; Campbell, A.B. and Hannah, A.E. 1948. A diagrammatic scale for estimating rust intensity on leaves and stems of cereals. Can. J. Res. Sect. C., 26: 496-500.

Raheja, A.K. 1977. Pest and disease relationships within various crop mixtures. Research Program 1977-78. H. Cropping Systems. Institute for Agricultural Research, Samaru, Nigeria pp: 4.

Ramert, B.M. and Lennartsson, D.G. 2002. The use of mixed species cropping to manage pests and diseases-theory and practice. Proceedings of the COR Conference, March 26-28, Aberystwyth, pp: 207-210.

Salama, H.S.A.; El-Karamity, D.E. and Nawar, A.I. 2016. Additive intercropping of wheat, barley, and faba bean with sugar beet: Impact on yield, quality and land use efficiency. Egypt. J. Agron., 38: (3) 413-430.

Shahin, S.I., 2017. Effect of some biocides on development of the onion downy mildew diseases, caused by Peronospora destracture (Berk.). Egyptian Journal of Biolological Pest Control, 27(1): 71-77.

Shane, W.W. and Teng, P.S. 1992. Impact of Cercospora leaf spot on root weight, sugar yield and purity of Beta vulgaris. Plant Dis. Rep., 76(8): 812-820.

Song, Y.N.; Zhang, F.S.; Marschner, P.; Fan, F.L.; Gao, H.M.; Bao, X.G.; Sun, J.H. and Li, L. 2007. Effect of intercropping on crop yield and chemical and microbiological properties in rhizosphere of wheat (Triticum aestivum L.), maize (Zea mays L.), and faba bean (Vicia faba L.). Biol. Fertil. Soils., 43:565-574.

Steel, R.G.D. and Torrie, J.H. 1980. Principle and procedures of statistics, a biometrical approach Mc Grow-Hill Book Company- $2^{\text {nd }}$ ed. 633p.

Sugha, S.K. and Singh, B.M. 1991. Status of Downy mildew of onion (Peronospora destructor) in Kangra district of Himachal Pradesh and its effect on crop yield. Plant Dis. Res., 6: 35-38.

Survilienè, E.; Valiuškaite, A. and Raudonis, L. 2008. The effect of fungicides on the development of downy mildew of onions. Zemdirbyste Agriculture, 95(3): 171-179.

Egypt. J. Phytopathol., Vol. 47, No. 1 (2019) 
Townsend, G.R. and Heuberger, J.W. 1943. Methods for estimating losses caused by disease in fungicide experiments. Plant Dis. Reptr., 27(17): 340-343.

Trenbath, B.R. 1993. Intercropping for the management of pests and diseases. Field Crops Research, 34(3-4): 381-405.

Usmanikhail, M.U.; Tunio, S.D.; Jamro, G.H.; Oad, F.C.; Hassan, U.1.; Waseem S.; Chachar, Q.D. and Khanzada, M.A. 2013. Effect of intercropping cereals and lentil in sugar beet on yield and monetary benefits. Pak. J. Bot., 45(2): 401-406.

Vandermeer, J. 1989. The Ecology of Intercropping. Cambridge University Press, Great Britain pp.237.

Willey, R.W. 1979. Intercropping-Its importance and research needs. Part 1, Competition and yield advantages. Field Crop Abstracts, 32: 1-85.

Zhang, F.S. and Li, L. 2003. Using competitive and facilitative interactions in intercropping systems enhance crop productivity and nutrient use efficiency. Plant and Soil, 248: 305-312.

Corresponding author: Khalifa, M.M.A.

E-mail: drmmakhalifa2014@gmail.com

(Received 14/04/2019;

in revised form 28/04/2019) 


\section{تأثير نموذجين لتحميل البصل مع بنجر السكر علي الإصابة ببعض أمراض المجموع الخضري وإنتاجية كلا المحصولين

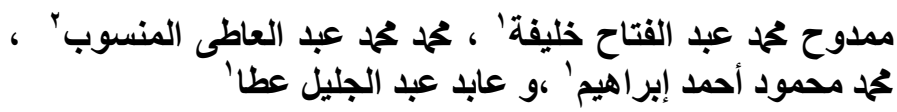

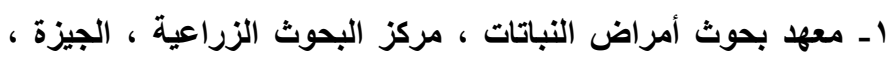

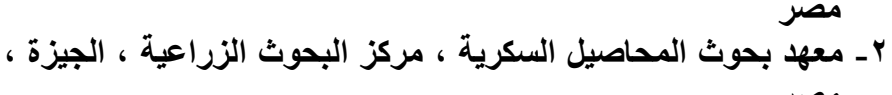

أجري هذا البحث لدراسة تأثير نموذجين مختلفين لتحميل محصول

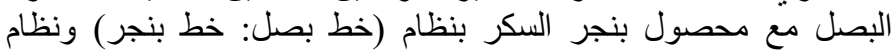

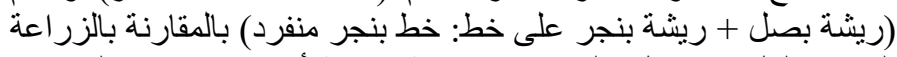

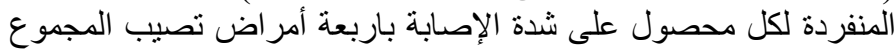

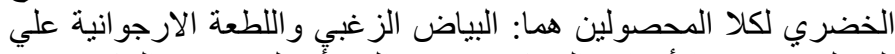

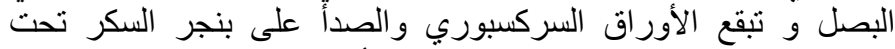

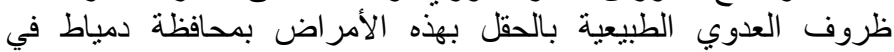

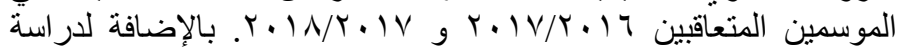

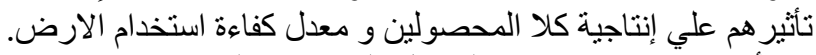

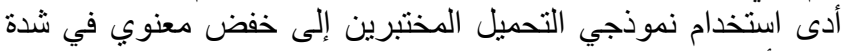

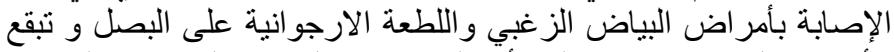

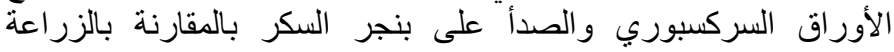

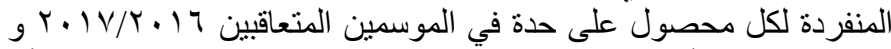

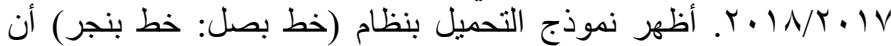

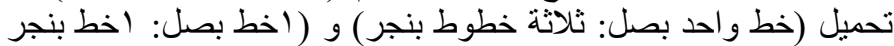

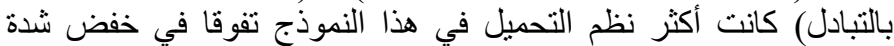

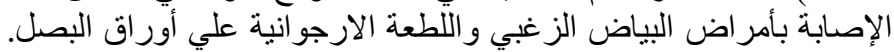

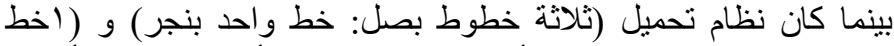

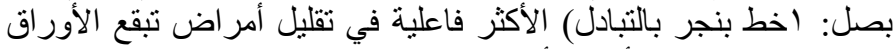

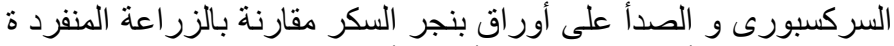

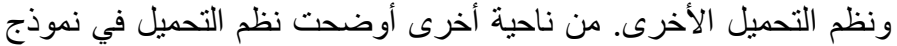

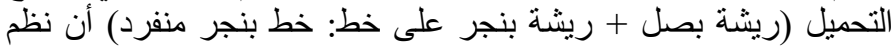

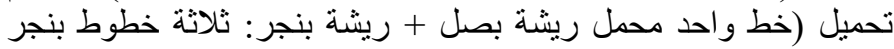

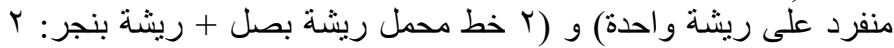

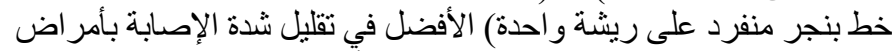

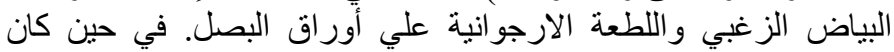

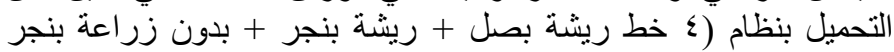

Egypt. J. Phytopathol., Vol. 47, No. 1 (2019) 


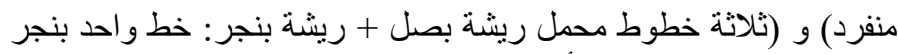

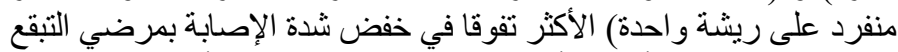

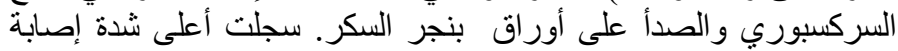

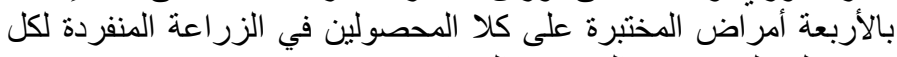
محصول على حدة في الموسمين المتعاقبين.

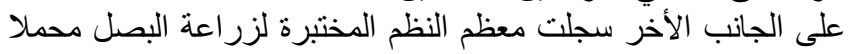

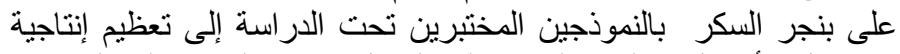

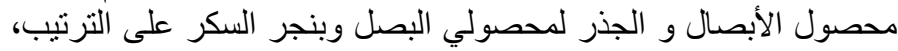

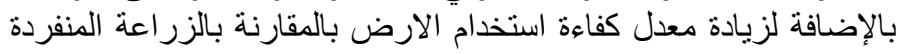

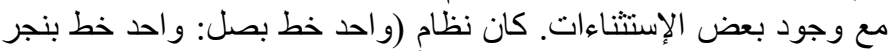

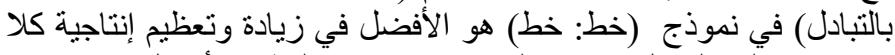

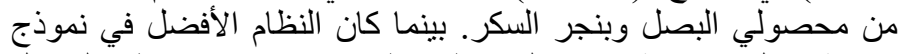

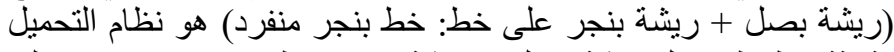

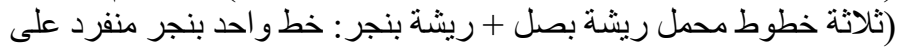

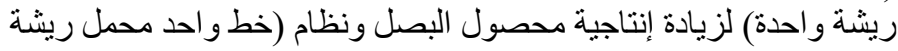
بصل + ريثة بنجر: ثلاثة خطوط بنجر منفرد) لزيادة إنتاجية محصول

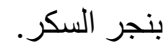

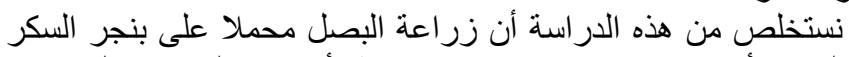

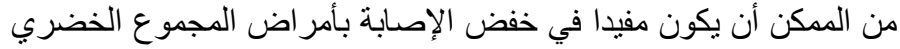

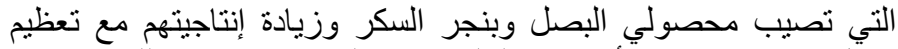

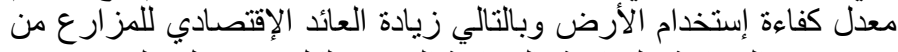

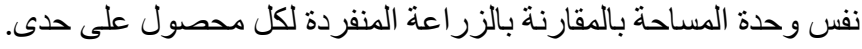

